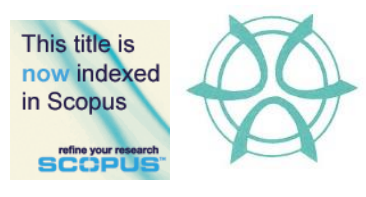

PLANNING MALAYSIA:

Journal of the Malaysian Institute of Planners

VOLUME 17 ISSUE 2 (2019), 62 - 73

\title{
APPRAISAL OF URBANISATION, TOWNSHIP AND HOUSING TRENDS FOR A DESIRED FUTURE IN MALAYSIA
}

\author{
Ruhizal Roosli ${ }^{1}$, Sana Malik ${ }^{2}$, Julaihi Wahid ${ }^{3}$, \& Helen Nesadurai ${ }^{4}$ \\ ${ }^{1,2}$ School of Housing, Building \& Planning \\ UNIVERSITI SAINS MALAYSIA \\ ${ }^{3}$ College of Engineering \\ AJMAN UNIVERSITY, UNITED ARAB EMIRATES \\ ${ }^{4}$ School of Arts and Social Sciences \\ MONASH UNIVERSITY, MALAYSIA
}

\begin{abstract}
This paper reviews the trend of township planning in Malaysia by featuring measures for the preparation of urban housing, and utilising the contemporary shifts in town 'landscaping'. Learning from the Habitat III, a competitive township is essential for better and vibrant society. In Malaysia, the competitiveness, capital at present can be measured in policy implementation financially and transformative technologies support with any cutting-edge human capital strategy. The objectives of this paper are to investigate the strategic angle of sustainable urban development and to suggest better future urbanisation, township and housing in Malaysia. Detailed review was done through content analysis aiming at well-being and economic stability of its residents. The content in focus comprised housing integration, housing assistance, economic participation, and technology and design. It was found that Malaysia must be aware and compatible with such challenges to align with the national aspiration for harmonious living standards for future planning and housing development.
\end{abstract}

Keywords: urbanisation, city planning, urban housing, urban policy, township 


\section{INTRODUCTION}

Until 2010, the total number of Malaysian households was 6,396,174 with the number of living quarters at 7,380,865 (JPM, 2011). Based on statistics, there are enough houses for every family, with an additional 984,691 more houses available in the market. Rightfully, the aim of government towards providing 'One Family One House' should have been fulfilled. However, the issue of insufficient housing still surfaces in Malaysia and has led to other problems such as the high prices of houses and limited affordability; abandoned housing projects, and unsold housing units (UNDP-EPU, 2015). These problems in turn would create other social problems such as homelessness and involvement in crime due to the stress and pressures faced in daily life (Kingsley, 2017). In order to solve these problems, meticulous 'physical' planning needs to be done, which indirectly would promote a harmonious social growth and resulting in a commendable social achievement (UNDP-EPU, 2015).

Therefore, an understanding of the needs and demands of the public is important, and should be seen from the viewpoints of the segmented status of individuals, households, and regional society (Jenkins, Smith, \& Ya Ping, 2007). For example, a social disadvantage would have an impact on an individual's education, which would lead to a job placement with a low salary. This could have been caused by the location of a school which was not strategic and hampered the schooling activities of students as mentioned in the New Urban UN-Habitat Agenda (Amann \& Jurasszovich, 2017). In order to understand the potential and direction in setting contemporary township with planned housing, there must also be an understanding on the smart township approach, housing concepts and the legal framework, especially at the local level, to serve as guidelines in planning decision-making process.

\section{METHODS AND MATERIALS}

The work in this paper concentrated mostly on academic reports of original investigations rather than reviews apart from the following in Table 1. These databases are in both electronic form and printed form, and are continuously being updated. Reviews and reports on the township and housing trend include the following (Table 1):

Table 1 Reviews and reports

\begin{tabular}{ll}
\hline Author & Theme \\
\hline $\begin{array}{l}\text { Construction Industry Development Board (CIDB) } \\
\text { Malaysia }\end{array}$ & Country Report \\
\hline Economic Planning Unit & Malaysia Plan \\
\hline Green Building Index (GBI) & Sustainable Assessment Criteria \\
\hline Department of Statistics (JPM). & National Census \\
\hline United Nations & World Urbanisation Prospects \\
\hline United Nations & Social Housing \\
\hline United Nations & Future Cities \\
\hline
\end{tabular}


Ruhizal Roosli, Sana Malik, Julaihi Wahid, \& Helen Nesadurai

Appraisal of Urbanisation, Township and Housing Trends for a Desired Future in Malaysia

\begin{tabular}{ll}
\hline $\begin{array}{l}\text { United Nations Development Programme \& Economic } \\
\text { Planning Unit }\end{array}$ & Urbanisation in Malaysia \\
\hline UN-HABITAT & Urban Policy \\
\hline UN-HABITAT & Housing Policy \\
\hline World Bank & Township \\
\hline
\end{tabular}

Detailed review of the above research was conducted through content analysis of township and housing trends in the future aiming at well-being and economic stability of its residents. The content in focus comprised housing integration, housing assistance and economic participation as in Table 2.

Table 2 Contents focus

\begin{tabular}{ll}
\hline Main Author/s & Theme \\
\hline Phillimore (2017) \& Weiss (2015) & Housing Integration \\
\hline Kingsley (2017) \& UN-HABITAT (2015) & Housing Assistance \\
\hline Ong et al. (2017), UN (2014), EPU (2015), Song (2015) & Economic Participation \\
\hline Petit et al. (2018), Oberndorfer et al., 2007, & Technology \& Design \\
Satiennam, Jaensirisak, Satiennam, \& Detdamrong & \\
(2016) \& Gunawan (2015) & \\
\hline
\end{tabular}

The conclusions in this paper are generalisations founded on the authors' interpretation of those original reports based on the contents. The review revealed some literature databases and overviews, notably from Asian context, focusing on Malaysia in particular. The objectives are to investigate the strategic angle of sustainable urban development and to suggest better future urbanisation, township and housing in Malaysia.

\section{THEORETICAL FRAMEWORK}

Reports with reviews on township, housing policy and trends have been published in several countries. In the Malaysia, in particular, there are government sponsored promotional publications about these particular topics such as the Malaysia Plan Documents and the National Census. Meanwhile, in the International arena, mostly these particular topics being covered by the World Bank and UN-HABITAT are included for consideration. Planning for the provision of housing through mixed development or otherwise would be determined by the various policies set by the relevant authorities. In Malaysia, there are four main guiding pillars for the nation to progress towards becoming a high-income, developed nation by 2020 (EPU, 2015). These pillars are:

- 1 Malaysia Concept;

- Government Transformation Programme (GTP/PTK);

- New Economic Model; and

- Malaysia 5-Year Plans 
PLANNING MALAYSIA

Journal of the Malaysia Institute of Planners (2019)

These policies would determine the form and direction of the Nation's plans. The government has outlined three main components encompassing human capital, private capital and social capital (EPU, 2015). The three components play essential roles and without these components, any major plan made by the government for the development of the people and the country would be impossible to be realized. For example, these components serve as the stimuli in the legislation of the National Social Policy. Other policies which have resulted from the implementation of the main policies concerning the provision of housing are as follows:

- National Housing Policy (Dasar Perumahan Negara)

- National Urbanisation Policy (Dasar Perbandaran Negara/DPN)

- National Physical Plan (Rancangan Fizikal Negara/RFN) which include the National Physical Plan (RFN), State Structure Plan (RSN), District Local Plan (RTD) and Special Area Plan (RKK) at the state and district levels.

\section{Township Trends Globally, in Asia and Malaysia}

In a nutshell, a township is a built-up or developed area having a population exceeding 10,000 people. There are five categories of townships as shown in Table 3. In 2014, more than half of the world's urban population live in areas with fewer than 500,000 people, especially in Asia (Figure 1). All over the world, there are more people living in urban areas compared to those living in rural areas. Rapidly developing cities need to cope with the unprecedented growth before 2025 where an additional 2 billion new urban residents by the mid-2020s with most of the growth occurring in South and East Asia (Cohen, 2004). The urban population around the world is expected to increase to more than two-thirds by 2050. Even though its urbanisation process is at a lower rate, Asia is the choice for 53 percent of the world urban dwellers up until 2014. It is anticipated that, the urbanisation process in Asia, including Africa would occur rapidly compared to the rest of the world in the future, as the economy grows more rapidly (UN, 2014).

Table 3: Classification of cities

\begin{tabular}{ll}
\hline Types of city & No. of people \\
\hline Megacity & $>10,000,000$ \\
\hline Major city & $5,000,000-9,999,999$ \\
\hline Medium city & $1,000,000-4,999,999$ \\
\hline Town & $500,000-900,000$ \\
\hline Small Town & 500,000 \\
\hline & Source: World Bank $(2015)$
\end{tabular}

In 2007, for the first time in history, the global urban population exceeded those living in the rural areas, and the world population has remained mostly in urban locations since then. This planet has undergone a rapid urbanisation process for the last six decades. In 1950, more than two-thirds (70\%) of the population 
Ruhizal Roosli, Sana Malik, Julaihi Wahid, \& Helen Nesadurai

Appraisal of Urbanisation, Township and Housing Trends for a Desired Future in Malaysia

around the world lived in rural settlements and less than one-third (30\%) lived in urban locations. In 2014, 54\% of the world population was living in towns. In United Kingdom, $90 \%$ of the population lives in urban areas, in the United States more than $80 \%$, in Germany more than $70 \%$, in Japan more than $65 \%$ and in France, above $60 \%$. Urban dwellers are expected to increase in number until the year 2050, when the world population would become one-third in rural areas (34\%) and two-thirds in townships and cities (66\%), a reversal of what was the scenario in the 1950s (UN, 2014).

Since the time Malaysia has gained independence, the urbanisation process has been occurring rapidly and the establishment of townships is unavoidable. Malaysia is one of the countries in East Asia, which is advancing in many aspects, and the urban population continues to multiply with each passing moment (CIDB, 2014). Figure 1 shows the change in the Malaysian landscape, from being dominantly covered forests in areas undergoing exploration.

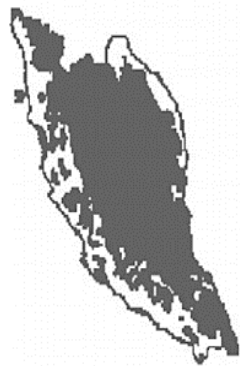

Year 1954 $9.5 \mathrm{mil}$ hectares

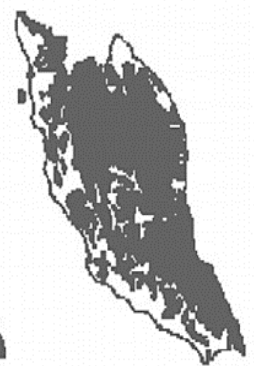

Year 1969 8.0mil hectares

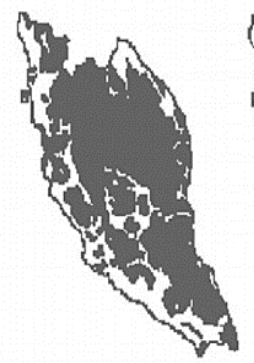

Year 1972

7.4mil hectares

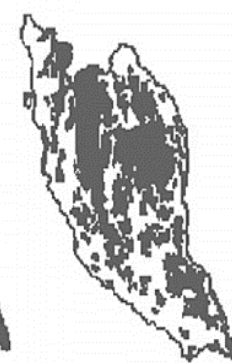

Year 1990 $6.2 \mathrm{mil}$ hectares

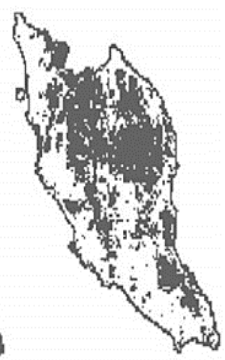

Year 2000 6.0mil hectare

Figure 1 Reduction in forest areas, replaced with other categories Source: World Bank (2015)

The Malaysian urban population has increased between 2000 to 2010 from 10.2 million (43\% of the total population) to 15 million (53\%), making it as among the countries with a high urbanisation rate in the region in terms of demography, next to Japan, Republic of Korea, and Singapore (and also Taiwan, China) (UN, 2014). According to the World Urbanisation Prospects (UN, 2014), Malaysia has $72.8 \%$ of its population living in urban areas in 2011. This is expected to increase to $77.9 \%$ (higher than the official target of $73.5 \%$ ) by 2020 , with an average urban growth rate of $2.08 \%$ between 2015 and 2020. Nevertheless, the urban areas in Malaysia on average are among those with the lowest density in East Asia (including Japan \& South Korea), with the overall density of the urban population at 3,300 people per kilometre square in 2010, which had increased from 2,600 people per kilometre square in 2000, and is much lower compared to the regional density rate (East Asia), which on average is about 5,800 per kilometre square (World Bank, 2015). 
PLANNING MALAYSIA

Journal of the Malaysia Institute of Planners (2019)

Until 2010, Malaysia has 19 urban areas with more than 100,000 people, which comprised Kuala Lumpur (urban area with more than 5 million people); George Town (between 1 million and 5 million people); Johor Bahru (5 urban areas having between 500,000 to 1 million people); and 12 other urban areas between 100,000 and 500,000 people. During the same period, the Kuala Lumpur urban area was the largest in Malaysia and the eighth biggest in the East Asian region, bigger than some of the urban megacity areas such as Jakarta, Manila, and Seoul, although with fewer number of people. It increased from about 1,500 per kilometre square to 1,700 between 2000 and 2010, with an average annual growth rate of $1.2 \%$, considered to be among the lowest growth rate for an urban area of similar size in the region (JPM, 2011).

\section{ANALYSIS \& DISCUSSIONS}

\section{The Adaptation Process of Planning in Malaysia}

In Malaysia, practically the international conventions as proposed by international bodies would be adapted to suit the local conditions (UNDP-EPU, 2015). The concept of liveable towns or cities was also adapted from such international standards. The concept of liveable townships firstly requires it to be viewed from the perspective of the current practical planning framework. The term liveability is usually used to portray the various shared aspects of society, the surroundings, and the experiences that would shape the society. Liveability brings into focus the human experiences in a particular place at a particular time. There is an interconnectedness in this situation, among the economic, social and spatial components which could be linked during the planning and development stages. Thus, in the planning for the provision of housing, consideration needs to be given to the combined components of the economic stimulus, spatial and social aspects. In principle, from the viewpoint of planning and the provision of housing, the combination of 'housing assistance' and 'economic participation' for the public housing needs to be understood clearly (UN-HABITAT, 2015). At the same time, the role of the private sector in providing housing in other categories would also depend on market demands, as offering houses which are unsuitable would lead to them being unsold.

For example, condominiums and apartment units built on the outskirts of towns throughout the country faced difficulties of being sold within the first six months after they were launched. It is a fact that, any housing development that does not take into account the economic participation of the designated population, the provision of such housing would be deemed a failure. This is due to the lack of financial input from the local populace, which would impede the dynamics of economic growth, and tend to have negative effects on social growth (UN, 2014). For example, a housing development project needs to consider mixed planning or economic stimulus activities in the surrounding areas. Mixed 
Ruhizal Roosli, Sana Malik, Julaihi Wahid, \& Helen Nesadurai

Appraisal of Urbanisation, Township and Housing Trends for a Desired Future in Malaysia

development would consist of components for housing, utilities and facilities, commercial, industries, and institutions among others. Indirectly, there would be a fair representation of activities for the population that would encourage pursuits such as job opportunities, recreation, services and others of similar nature. Mixed development in Malaysia has long been in practice. Previous research has also shown that when amenities and commercial outlets are within walking distance or under shelter from the main door of the housing unit to the outlets, the percentage of foreclosures dropped drastically (Song, 2015). This means the emphasis is on walkability within the housing area is important for the development to be vibrant (Roosli \& Collins, 2016).

\section{The Future Challenges of Future Housing in Malaysia}

Housing in the future for Malaysia will revolve around the theme of integration. Integration of housing can be seen in two aspects, which is an integration of housing as a township through the creation of smart cities (digital planning) and the integration of housing at the personal level by designing smart homes (Phillimore, 2017). Integration of housing as a satellite township shall be supported by infrastructure for connectivity, facilities for conveniences (high-end and high-touch), and comprehensive planning for township identity (Phillimore, 2017). On the other hand, integration of housing at the personal level is about having houses that provide good quality of life with customised designs and multi-purpose space. The result of this can be translated into three distinct ways (Weiss, 2015). Firstly is the general evolution in the characteristics of housing units. This will be seen as newer building methods and designs strive to overcome increases in density and cost of land. Secondly, can be seen in the environment around housing where cities will continue to mature and increase in density allowing for viability of more public services and spending. Thirdly, the combination of both ways in order to create a rapid increase in demand for certain combination of housing units such as mixed developments to be discussed later.

As land becomes scarcer in urban areas, it is expected that future housing units will be smaller in size. With that in mind, future housing estates that are dense should be designed with more communal spaces, especially in high-rise living to allow areas for people to engage in social activities. Vertical village living with the ambience of on the ground setting is envisioned by urban planners and architects as a solution for urban housing in Malaysia. Hence, more houses will be designed to cater for lives where eating, resting, working and living are brought together.

Increasing features for liveability will also be the mainstream in the future. The connectivity of future housing should be seen within the same area through building connectors that are either underground or linked through sky bridges. This linkage will increase the walkability within an area and reduce the need for cars. Currently, this trend is common among commercial and public 
PLANNING MALAYSIA

Journal of the Malaysia Institute of Planners (2019)

areas. Some good examples are in Singapore, Mandarin Oriental Hotel and Pan Pacific Serviced Suites are both linked to mandarin Gallery Mall via shaded walkways, while Bugis Junction and Bugis+ are two commercial outlets linked via a sky bridge. The famous shopping center One Utama in Damansara, Kuala Lumpur comes also with a bridge between two commercial buildings. Nonetheless, this concept can be extended to residential buildings that are not mixed development. For example Marina Bay Residences in Singapore has an underground pass that leads straight into the Downtown MRT and link mall. This concept may attract some reservation as security issues may be a concern. However, more safer and shaded walkways between buildings can be built as a start. The shaded walkways that are constructed shall be wide enough to cater for pedestrians, scooters, sedgeways, hover boards and the likes. Subsequently, with more people walking and less cars required, car parks can be turned into green areas by creating pocket parks.

In order to increase availability of public transportation in urban expansion, the existing and future housing estates have to be supported by good public transportation and infrastructure to ensure the connectivity between different areas (Petit et al., 2018). Some of the systems that can be emulated to improve connectivity are the Bus Rapid Transit system (BRT) in Jakarta, Indonesia, which is the world's largest BRT system, and the Bike Sharing program in Hangzhou China, Taipei Taiwan and Brisbane Australia.

Launched in 2004 by the city administration of Jakarta, TransJakarta was the first BRT system in Southern and Southeast Asia with dedicated bus-only lanes, at level boarding platforms and pre-ticketing. It has successfully converted private motorised vehicle users into BRT riders, which makes up 20\% of BRT passengers (Satiennam et al., 2016). Currently TransJakarta has the world's longest BRT system with 13 primary routes and 11 cross-corridor routes with more corridors due to commence construction. In addition, there are 17 'city feeder' routes that continue past the end of the exclusive bus ways into the municipalities surrounding Jakarta and use special buses that allow for boarding at either ground level or the TransJakarta station platforms (Gunawan, 2015).

In Hangzhou, the city provides the largest public bicycle fleet in the world. Launched in 2008, the service allows members to access a shared fleet of bicycles. As of March 2011, Hangzhou Public Bicycle operated 60,600 bicycles with 2,416 fixed stations in eight core districts. Bike sharing in Hangzhou captured modal share from bus transit, walking, automobiles and taxis (Shaheen, Zhang, Martin, \& Guzman, 2011). Approximately 30\% of members had incorporated bike-sharing into their most common commute. Members indicated that they most frequently used a bike sharing station closest to either home (40\%) or work (40\%). These modal shifts suggested that bike sharing acted as both a competitor and a complement to existing public transit. 
Ruhizal Roosli, Sana Malik, Julaihi Wahid, \& Helen Nesadurai

Appraisal of Urbanisation, Township and Housing Trends for a Desired Future in Malaysia

Malaysia is gradually moving towards the direction of having better public transportation to improve connectivity between districts. It is most evident in Kuala Lumpur (KL) and Greater KL with the existing bus, monorail, commuter and Light Rail transit (LRT) systems, BRT system implemented in Sunway in 2015 with extensions planned, and the Mass Rapid Transit (MRT) system that will serve areas along Sungai Buloh to Kajang, which is expected to be ready by 2017. Upon completion of the high-speed rail in 2026, connectivity in Greater KL will eventually span through six other cities, namely Putrajaya, Seremban, Ayer Keroh, Muar, Batu Pahat and Iskandar Puteri before terminating in Singapore's Jurong East. In Penang, the State commissioned a Transport Master Plan Strategy report with the aim to improve the State's present transport system from now until 2030 by constructing three new highways in Penang Island and a third undersea tunnel project. Plans for BRT, LRT and monorail systems are also in place. The suitability of each system has to be carefully studied before being implemented in each area.

One of the key aspects of successful mixed development is the economy of scale (Ong et al., 2017). As mixed development is usually expected to have a mix of residential units with varied facilities, commercial outlets, offices and institutions within the area, it is crucial that the development is supported by a large enough population in order for synergy to take place. There is a win-win effect for residential and commercial outlets to be located on the same estate. The residents of the estate will benefit from the convenience available, while the commercial outlets will have a thriving business. Mixed development allows residents to have a live-work-play lifestyle as the distances between housing, workplaces, commercial businesses and other destinations are reduced, thus transpiring walkable neighbourhoods. The compact development also allows for a stronger neighbourhood character to form and becomes a self-sustaining township.

Housing plays a big part in the national environmental initiatives. Future housing will be designed with more electric cars charging point. As of 2016, the Green Building Index (GBI) does not require GBI certified residential buildings to provide car parks for green vehicles. Currently, this agreement is only applicable to the non-residential development to have 5\% of its car park to be allocated to green vehicles for a score of 1 point (Green Building Index, 2009). In the next 20 years, it is plausible that GBI will implement $30 \%$ green car parks requirement in order to achieve the green initiatives (Petit et al., 2018).

Rainwater harvesting systems will also become common in future housing, especially in Malaysia which has a tropical climate. The rainwater collected can be used for irrigation and washing. Water bills will be reduced in the housing estates. Green roofs would also be the future demand as this is an emerging trend, reducing storm-water runoffs, improve regulation of building interior indoor temperature, reduce urban heat island and increase urban wildlife 
PLANNING MALAYSIA

Journal of the Malaysia Institute of Planners (2019)

habitat (Oberndorfer et al., 2007). Similarly, vertical landscaping is also an emerging design trend. An example of residential building with plenty of vertical landscaping is Le Nouvel in Kuala Lumpur. Sustainable choice of plants is needed for green roofs and vertical landscaping. For instance, native and drought tolerant plants such as grasses, herbs and sedums, can be chosen for this purpose.

Based on the lessons learnt from past developments on townships, development should not be focused only on specific towns or cities such as in Kuala Lumpur (Weiss, 2015). The development of satellite townships too need to be considered. In planning for development, it needs to take into account achieving equilibrium between the urban and rural areas (Kingsley, 2017). For example, the concept of a 21 st-century village, if introduced, would be truly relevant to the current situation in Malaysia. Besides providing the balance between the migration of the urban and rural population, this concept has proven to be effective in Japan and the Netherlands. Rural areas too need to be designed based on the liveable town component, as they could function as the stimuli and counter the effects of widespread urbanisation. However, in countries such as Japan and the Netherlands, there is strong support for the development of public transport services that is efficient and exemplary.

\section{CONCLUSION}

Housing industry cannot be seen independently and has to be integrated with other aspects for quality and comfortable homes to be visible. Housing in the future needs to be supported by many aspects such as infrastructure, transportation, technology, improved architecture and engineering, and development of sustainable products to achieve a high performing building standard. It will be a remarkable achievement if this envision of housing becomes a reality sooner (within the next 20 years) than later. In the further future, the housing benchmark can be further elevated by creating housing that can produce its own energy and is self-sustainable. Although the developed countries have allocated substantial amounts from their budget on social expenditure, there are still many unaddressed housing issues such as vandalism, homelessness, and community segregation. Learning from all of these challenges, 'physical' planning needs to be aligned with the needs and demands of the public which indirectly would promote a harmonious social growth and resulting in a commendable social achievement for future housing trends in Malaysia.

\section{ACKNOWLEDGEMENTS}

This research work was funded by Ministry of Education Malaysia through its KPT (B) SLAB/SLAI Scheme. The authors gratefully acknowledge use of facilities at Monash University, Malaysia. 
Ruhizal Roosli, Sana Malik, Julaihi Wahid, \& Helen Nesadurai

Appraisal of Urbanisation, Township and Housing Trends for a Desired Future in Malaysia

\section{REFERENCES}

Amann, W., \& Jurasszovich, S. (2017). Habitat III - A critical review of the New Urban Agenda. (n.p.): Housing Finance International.

CIDB (2014). Country Report: Malaysia. 20th Asia Construct Conference Hong Kong, November 13-14, 2014, Kuala Lumpur.

Cohen, B. (2004). Urban growth in developing countries: A review of current trends and a caution regarding existing forecasts. World Development, 32(1): 23-51.

EPU (2015). Rancangan Malaysia ke-11 (RMK-11). Putrajaya: Unit Perancang Ekonomi. Jabatan Perdana Menteri.

Green Building Index (2009). GBI Assessment Criteria for Non Residential New Construction (NRNC) (1.0). Kuala Lumpur: Greenbuildingindex Sdn. Bhd.

Gunawan, F. (2015). Empirical assessment on factors affecting travel time of bus rapid transit. International Journal of Engineering and Technology, 7(1), 327-334.

Jenkins, P., Smith, H., \& Ya Ping, W. (2007). Planning and housing in the rapidly urbanising world. New York: Routledge.

JPM (2011). Laporan kiraan permulaan: banci penduduk dan perumahan Malaysia. Putrajaya: Jabatan Perangkaan Malaysia.

Kingsley, G. T. (2017). Trends in housing problems and federal housing assistance. Washington: Urban Institute.

Oberndorfer, E., Lundholm, J., Bass, B., Coffman, R. R., Doshi, H., Dunnet, N., \& Rowe, B. (2007). Green roofs as urban ecosystems: Ecological structure, functions and services. BioScience, 57(10), 823-833.

Ong, R., Wood, G. A., Whelan, S., Cigdem-Bayram, M. Atalay, K., \& Dodson, J. (2017) Inquiry into housing policies, labour force participation and economic growth. Melbourne: AHURI.

Petit, C. Liu, E., Rennie, E., Goldenfein, J., \& Glackin, S. (2018). Understanding the disruptive technology ecosystem in Australian urban and housing contexts: A roadmap. Melbourne: AHURI.

Phillimore, J. (2017). Embedded integration and organisational change in housing providers in the UK. Social Policy and Society, 16(1), 1-14.

Roosli, R., \& Collins, A. E. (2016). Key lessons and guidelines for post-disaster permanent housing provision in Kelantan, Malaysia. Procedia Engineering, 145, 1209-1217.

Satiennam. T., Jaensirisak, S., Satiennam, W., \& Detdamrong, S. (2016). Potential for model shift by passenger car and motorcycle users towards bus rapid transit (BRT) in an Asian developing city. IATSS Research, 39(2), 121-129.

Shaheen, S., Zhang, H., Martin, E., \& Guzman, S. (2011). China's Hangzhou public bicycle. Journal of the Transportation Research Board, 2247, 33-41.

Song, K. B. (2015). Liveable and sustainable cities: Common challenges, shared solutions. World Cities Summit, June 1-4, 2014, Singapore.

UN (2014). World urbanization prospects. New York, United Nations Department of Economics and Social Affairs Population Division.

UNDP-EPU (2015). Study on housing for the bottom $50 \%$ income group and the challenges of urbanization in Malaysia. Kuala Lumpur: United Nations Development Programme and Economic Planning Unit of Malaysia. 
PLANNING MALAYSIA

Journal of the Malaysia Institute of Planners (2019)

UN-HABITAT (2015). Green building interventions for social housing. Nairobi: UNHABITAT.

Weiss, M. L. (2015). Handbook of contemporary Malaysia. New York: Routledge.

World Bank (2015). East Asia's changing urban landscape measuring a decade of spatial growth. Washington: World Bank Group

Received: $30^{\text {th }}$ November 2018. Accepted: $19^{\text {th }}$ August 2019 